Prepared for the U.S. Department of Energy

under Contract DE-AC05-76RL01830

\title{
Human Portable Radiation Detection System Communications Package Evaluation
}

\author{
GP Morgen \\ WW Peterson
}

June 2009

\section{Pacific Northwest}

NATIONAL LABORATORY

Proudly Operated by Battelle Since 1965 


\title{
DISCLAIMER
}

This report was prepared as an account of work sponsored by an agency of the United States Government. Neither the United States Government nor any agency thereof, nor Battelle Memorial Institute, nor any of their employees, makes any warranty, express or implied, or assumes any legal liability or responsibility for the accuracy, completeness, or usefulness of any information, apparatus, product, or process disclosed, or represents that its use would not infringe privately owned rights. Reference herein to any specific commercial product, process, or service by trade name, trademark, manufacturer, or otherwise does not necessarily constitute or imply its endorsement, recommendation, or favoring by the United States Government or any agency thereof, or Battelle Memorial Institute. The views and opinions of authors expressed herein do not necessarily state or reflect those of the United States Government or any agency thereof.

\author{
PACIFIC NORTHWEST NATIONAL LABORATORY \\ operated by \\ BATTELLE \\ for the \\ UNITED STATES DEPARTMENT OF ENERGY \\ under Contract DE-AC05-76RL01830
}

Printed in the United States of America

Available to DOE and DOE contractors from the

Office of Scientific and Technical Information,

P.O. Box 62, Oak Ridge, TN 37831-0062;

ph: (865) 576-8401

fax: $(865) 576-5728$

email: reports@adonis.osti.gov

\footnotetext{
Available to the public from the National Technical Information Service, U.S. Department of Commerce, 5285 Port Royal Rd., Springfield, VA 22161 ph: (800) 553-6847 fax: (703) 605-6900

email: orders@ntis.fedworld.gov

online ordering: http://www.ntis.gov/ordering.htm
}

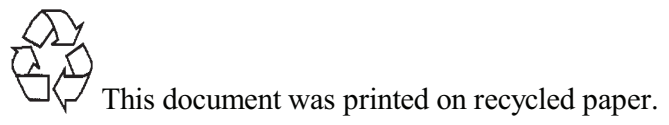

(9/2003) 


\section{Human Portable Radiation Detection System Communications Package Evaluation}

GP Morgen

WW Peterson

June 2009

Prepared for

the U.S. Department of Energy

under Contract DE-AC05-76RL01830

Pacific Northwest National Laboratory

Richland, Washington 99352 



\section{Summary}

PNNL recommends that DNDO (and/or CG) contact Sanmina and request a demo of the HCP Email data capability. The demo should include at a minimum three spectra data file attachments (background, known source, and unknown source) that are sent in the email package. The data should be sent using both included wireless cell phone hardware and the Iridium sat phone. The HCP has been optimized to operate on the Iridium Satellite Network, so that constraint needs to be factored into the selection of a service provider. It is also suggested that discussions with Sanmina work out the best method for CG personnel to use the HCP without requiring a separate email account for each HCP (e.g., similar to a BlackBerry using the member's email account), which should help make the HCP more user friendly. 



\section{Acronyms and Abbreviations}

$\begin{array}{ll}\text { CDMA } & \text { Code Division Multiple Access } \\ \text { CF } & \text { Compact Flash } \\ \text { CSD } & \text { U.S. Coast Guard } \\ \text { DNDO } & \text { Circuit Switched Data } \\ \text { GPRS } & \text { Gomestic Nuclear Detection Office } \\ \text { GSM } & \text { Global System for Mobile } \\ \text { HCP } & \text { HPRDS Communication Package } \\ \text { HPRDS } & \text { Human Portable Radiation Detection System } \\ \text { LED } & \text { Light Emitting Diode } \\ \text { LSS } & \text { Laboratories and Scientific Services (USCG facility) } \\ & \\ \text { RIID } & \text { Radiation Isotope Identification Device } \\ \text { SIM } & \text { Subscriber Identity Module } \\ \text { TDMA } & \text { Time Division Multiple Access }\end{array}$





\section{Contents}

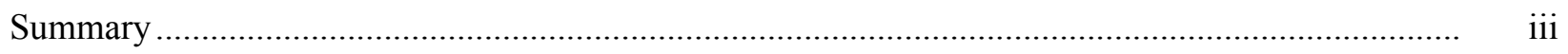

Acronyms and Abbreviations .............................................................................................

1.0 Human Portable Radiation Detection System Communications Package Hardware .................. 1

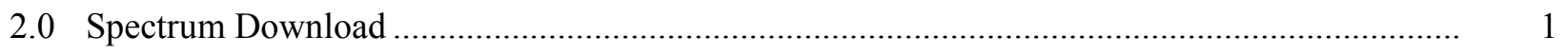

3.0 Spectrum Transfer and Cellular Service .................................................................................... 2

4.0 Enfora Wireless Cellular Modem and Internet - Email Access ............................................... 3

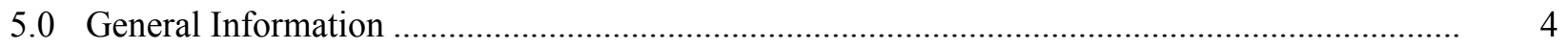

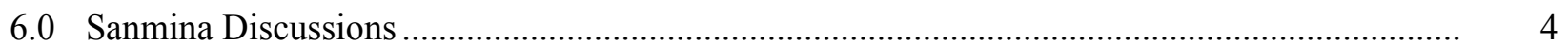

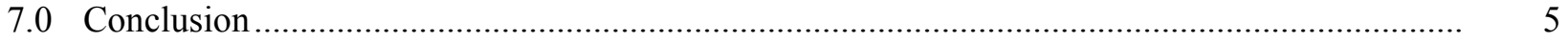





\subsection{Human Portable Radiation Detection System Communications Package (HCP) Hardware}

The main components of the HCP field kit are an Archer Field $\mathrm{PC}^{\circledR 1}$ and an Iridium satellite phone, along with various charging components and cables. The Archer Field PC has an Enfora Global System for Mobile/General Packet Radio System (GSM/GPRS) wireless cellular modem installed via the compact flash (CF) port. The Iridium satellite phone has a serial communication interface attached.

The Archer Field PC is running Windows Mobile ${ }^{\mathbb{B} 2} 5.0$ operating system. Included Microsoft

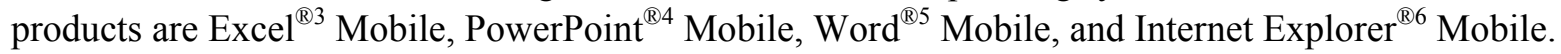
There is an Outlook ${ }^{\circledR 7}$ Email program that can be accessed via sending a file or the Messaging link. The Cambridge Computer Corporation vxHpc program is installed to provide a Hyperterm-like software product. vxHpc supports multiple communication protocols.

An AT\&T SIM card was provided for the GSM wireless cellular modem. A check with AT\&T determined the SIM card was not activated to provide cellular service. The Iridium satellite phone did not have a SIM card and has no service.

The Archer Field PC boots into a HCP program, displaying the Main Menu. The following actions can be executed by selecting the appropriate box: [1] Spectrum Download, [2] Spectrum Transfer, and [3] Admin Control. The Spectrum Download function uses the serial communication port to download data files from another device, such as a Radiation Isotope Identification Device (RIID). The Spectrum Transfer function uses either the installed wireless cellular modem or the Iridium satellite phone (attached to the serial communication port) to send data files to a computer modem at the Laboratories and Scientific Services (LSS). The Admin Control function allows entering phone numbers and data file deletion.

\subsection{Spectrum Download}

The Spectrum Download function was tested by connecting to a RIID at Pacific Northwest National Laboratory (PNNL). The Archer Field PC and the RIID were connected via the provided serial communication cable [9-pin RS232]. Initially one file was downloaded, then "download all files" was selected, which resulted in 12 files being downloaded. There were more than 12 files to download, but with a total of 13 files this seemed sufficient to test the transmit function.

\footnotetext{
${ }^{1}$ Archer Field PC is a registered trademark of Juniper Systems Inc.

${ }^{2}$ Windows Mobile is a registered trademark of Microsoft Corporation.

${ }^{3}$ Excel is a registered trademark of Microsoft Corporation.

${ }^{4}$ PowerPoint is a registered trademark of Microsoft Corporation.

${ }^{5}$ Word is a registered trademark of Microsoft Corporation.

${ }^{6}$ Internet Explorer is a registered trademark of Microsoft Corporation.

${ }^{7}$ Outlook is a registered trademark of Microsoft Corporation.
} 
The downloaded files were stored in two locations - folders under My Device/Program Files. The Data folder contains copies of the original data files downloaded (text version), while the Connections folder contained a version of the data files that had been altered. The Connections folder data files were not readable as a text file; therefore it is assumed that these are the encrypted version of the data files.

\subsection{Spectrum Transfer and Cellular Service}

In order to test the Spectrum Transfer function, cellular service needed to be setup and activated. Since the AT\&T SIM card in the HCP field kit was not active and belonged to the Domestic Nuclear Detection Office (DNDO)/U.S. Coast Guard (CG), it was decided not to activate this SIM. PNNL was authorized to obtain a SIM card and cellular service for evaluating the unit. A decision was made to investigate Verizon as a cellular service provider because it has greater coverage area in the Puget Sound region where training and testing was scheduled. It was determined that Verizon was not an option as a service provider. The Verizon cell system is based on CDMA technology, which is not compatible with the installed GSM wireless cellular modem. GSM/GPRS is based upon Time Division Multiple Access (TDMA) technology. Therefore, the choices are AT\&T or T-Mobile. AT\&T was chosen due to its larger coverage area.

An account was requested that would allow data transfer, circuit switched data, and Internet access. Getting the service setup to match the request was not straight forward. The HCP transmits data via a Circuit Switched Data (CSD) protocol. CSD is an older protocol that AT\&T supports mainly for the U.S. Government. The initial cell service plan setup by PNNL was described as an AirCard plan with data. Tests conducted trying to send a data file to a Sanmina test computer failed - "No Carrier" messages. Mark Baginski, project manager at Sanmina, assisted with getting the test computer setup. After several Spectrum Transmit tests and reporting the No Carrier messages, Mark Baginski again assisted by getting the circuit switched data part of the service setup through his AT\&T contacts. Circuit switched data being enabled within a service plan is not normal, and getting it functional required several iterations. Several times, Technical Support stated that this is the wrong service plan and that it needed to be changed, which required a call from the plan manager to make the changes. Being able to access the Enterprise Technical Help personnel was a great aid since they knew of circuit switched data and the requirements needed to get the service enabled on the plan.

The phone number assigned to the SIM card is 509-554-4746 and the final circuit switched data number is 509-554-8262. This is the fourth CSD number tried. The service being used was described as a PDA account with a 450 voice plan and circuit switched data service for approximately $\$ 95 /$ month.

Mark Baginski at Sanmina assisted with testing of the HCP by setting up one of their test computers/modems and provided the modem phone number, 256-882-4169. Several times a single test file was transmitted to the Sanmina test system, but most tries were not successful. At best, a data file was successfully transmitted approximately $1 / 10$ attempts. After the latest discussions with AT\&T technical support, one connection was made to the Sanmina test computer where three data files were transmitted during one connection. Many additional attempts to transmit three data files have failed, it has not been repeated. Failed attempts result in a "No Carrier" message, or just a timeout and returning to the HCP main menu. Sometimes the modem on the receive end doesn't answer, so the assumption is the call got lost. 
At this point, it has not been determined if the problem is on the transmit end, the service, or the receive end. During some of the transmit tests, an AT\&T cell phone was in close proximity to the Archer Field $\mathrm{PC}^{\circledR}$. The cell phone indicated four of five bars, which should indicate that there is good cell signal. The Enfora wireless cellular modem has an indicator LED that blinks green every five or six seconds indicating that the device is connected to the cell network.

There were several attempts made to transmit data files to the LSS. Successful data file transfer was not achieved. Most of the time, the receiver modem never responded to the call and the HCP would indicate "No Carrier" or would just timeout, going back to the HCP main menu. The last attempt to transmit data files to LSS was within 30 minutes of a successful transmission of three data files to the Sanmina computer/modem. This was the only time the LSS based computer/modem system showed any activity. Several times the LSS computer/modem system would respond to the call - there was some modem activity on the LSS end, but no connection was achieved. The comment on the LSS end was that the modem didn't seem to respond the same as observed on other occasions when data files where downloaded.

\subsection{Enfora Wireless Cellular Modem and Internet - Email Access}

The compact flash (CF) based Enfora (also WeiTel) GSM/GPRS wireless cellular modem plugs directly into the CF slot located on the top of the Archer Field PC. This assembly method makes a compact unit, with all electronics operating from the battery in the Archer Field PC. A complication with the Enfora GSM/GPRS wireless cellular modem, is that it is no longer supported (declared End-Of-Life) by WeiTel and Enfora. This limits any additional help or updates for the device.

Normal transmit operations are be to remove the Archer Cap ${ }^{\circledR}$ covering the modem and rotating the antenna $180^{\circ}$, although the Enfora User Guide indicates $90^{\circ}$ for the antenna operating position. There is a status indicator LED that blinks green once every six seconds when the modem is connected to a GSM network. Once AT\&T service was setup, the wireless modem has always connected to the network a short time after boot-up.

WeiTel support was contacted in an effort to get additional information concerning the wireless modem. WeiTel support stated the one technical person that supported the GSM0110 cellular wireless modem no longer worked at WeiTel and referred inquiries to Enfora.

Technical support at Juniper Systems (manufacturer of Archer Field PC) was contacted in an effort to get technical advice on setting up the Archer/wireless modem for Internet and Email access. Technical support could help getting through the setup process, but the BVRP (now Avanquest) phone tools CDROM that ships with the Enfora GSM0110 is required. The BVRP CDROM phone tools are not part of the HCP kit and phone tool files could not be located on the Archer Field PC ${ }^{\circledR}$; therefore Juniper Systems recommended contacting Enfora.

Enfora technical support is no longer supporting the GSM0110 and stated that BVRP is also not supporting the Enfora GSM0110. Due to license agreements, Enfora can only send/sell the BVRP phone tools CDROM with the hardware. Enfora suggested contacting one of their distributors - Simple 
Solutions (U.K.) - as they may have hardware and BVRP CDROM. An initial check of the Simple Solution website listed the Enfora GSM0110 as hardware only - OEM, no software. A check of the Simple Solutions website [5-19-2009] showed the Enfora GSM0110 Retail (hardware plus BVRP CD) as in stock for about $€ 125$ Euros. This is the only location found thus far that lists the BVRP CDROM phone tools for the Enfora GSM0110 that seem to be necessary to establish an Internet - Email connection.

Some other websites were contacted, mostly in Europe, and one response from a Swedish company stated that BVRP phone tools caused $90 \%$ of the problems and should not be used.

\subsection{General Information}

PNNL IT Help personnel tried setting up the initial internet access. They started by trying to setup another dial-up profile by copying an existing profile and making changes to the copy. When the modified dial-up profile was saved, the Archer Field PC locked up. The Archer could not be reset, and after about 30 minutes the battery was pulled to power down the Archer. When the battery was installed, the Archer had reset to factory default settings. The HCP program was gone; all software installed by Sanmina was erased. The Archer was returned to Sanmina so that the programs could be re-installed. The Archer was returned to PNNL for further testing. Removing the battery should not have caused a factory reset. The factory reset was unintended and accidental. A factory reset is possible by simultaneously pressing three buttons on the front of the Archer Field PC.

AT\&T technical support stressed that circuit switched data is not normal access for accounts and is enabled only for government accounts. AT\&T review teams daily verify access point numbers and if an account with circuit switched data enabled is found that is judged to be not valid, it is shut down. Therefore, circuit switched data for this account could be shut down in the future because the account name [DOE - PNNL] might not be recognized as a valid government account. If the circuit switched data access does get shut down, it would require the PNNL cell sales manager to get the service re-enabled.

\subsection{Sanmina Discussions}

Sanmina was contacted concerning the BVRP phone tools and general Internet - Email access and operations. The goal was to determine if the HCP could be setup to send the data files via Email directly to LSS without going through the computer - modem setup at LSS. The HCP was not configured for Email and communication timing parameters had to be tuned for Iridium operations. Sanmina did not use the phone tools. In discussions with Sanmina's Mark Baginski (project manager) and Dave Best (software engineer), it was concluded that Sanmina should be able to upgrade the current HCP with software and memory to have it use email to send spectra data directly to LSS without using the computer modem, connecting via either the cell phone or the Iridium. Sanmina has the software to modify the HCP to send email data. Sanmina also stated that they have modified one of their HCPs to accomplish this functionality in the cell phone configuration and that they feel it could be done via the Iridium sat phone. 


\subsection{Conclusion}

PNNL recommends that DNDO (and/or CG) contact Sanmina and request a demo of the HCP Email data capability. The demo should include at a minimum three spectra data file attachments (background, known source, and unknown source) that are sent in the email package. The data should be sent using both included wireless cell phone hardware and the Iridium sat phone. The HCP has been optimized to operate on the Iridium Satellite Network, so that constraint needs to be factored into the selection of a service provider. It is also suggested that discussions with Sanmina work out the best method for CG personnel to use the HCP without requiring a separate email account for each $\mathrm{HCP}$ (e.g., similar to a BlackBerry using the member's email account), which should help make the HCP more user friendly. 



\section{Distribution}

No. of

Copies

3 Offsite Distribution

1 MC Washlelski

Maritime Radiation Detection Program

U.S. Coast Guard Headquarters

2100 Second Street, SW

Washington, D.C. 20593

2 Domestic Nuclear Detection Office

U.S. Department of Homeland Security 245 Murray Lane, SW

Washington, D.C. 20528

CV Strangfeld

LR Simmons
No. of

Copies

\section{Onsite Distribution}

5 Pacific Northwest National Laboratory GP Morgen (2)

K5-17

WW Peterson (3) 




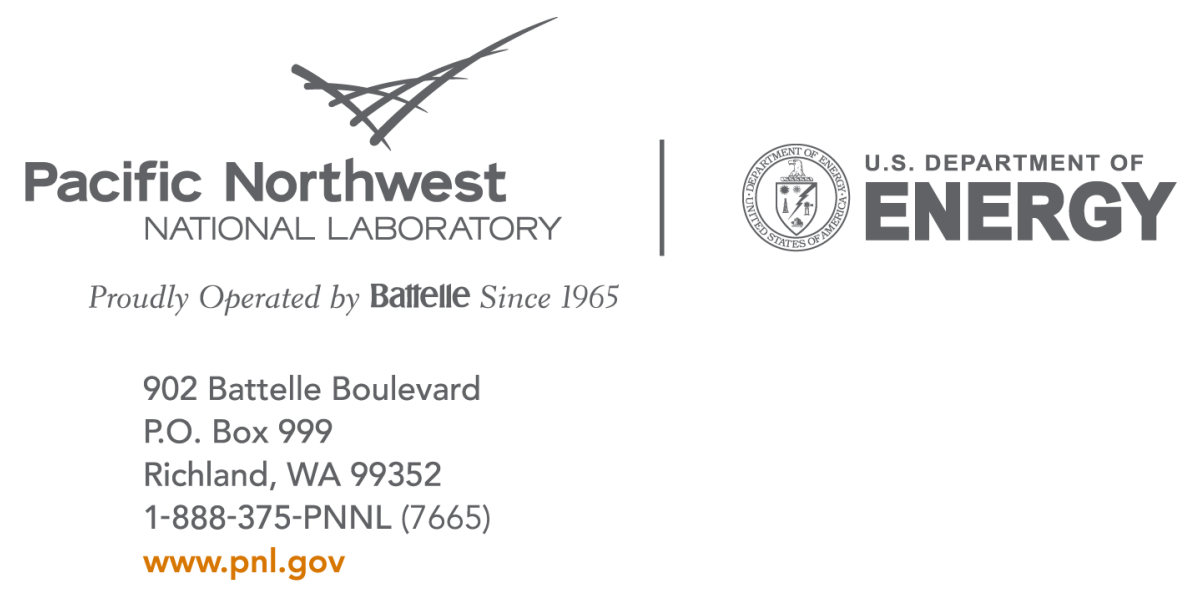

